\title{
POLITIK HUKUM PEMBENTUKAN PERATURAN DAERAH TENTANG ANGGARAN PENDAPATAN DAN BELANJA DAERAH
}

\author{
Muk t i \\ Mahasiswa Program Doktor Ilmu Hukum Pascasarajana UMI Makassar \\ email : mukti2016@gmail.com
}

\begin{abstract}
Establishment Law Politics Regional Regulation on APBD essentially includes local policies that are planned to be implemented in the framework of the public welfare. Regulation formation of local regulations on the budget, in its development has experienced a shift towards the better. Political law establishment of regional regulation on APBD ideal, if the Regional Regulation on the budget in accordance with the nature of the formation of regional regulations, in accordance with the hierarchy of legislation in Indonesia, in accordance with the principle of the establishment and the principles of the substance of the legislation, and made through the stages of formation Local regulation.
\end{abstract}

Keywords : Politic of Law; Regulatory Area;

\begin{abstract}
Abstrak
Hukum Pembentukan Politik Peraturan Daerah tentang APBD pada dasarnya mencakup kebijakan lokal yang direncanakan untuk dilaksanakan dalam rangka kesejahteraan masyarakat. Regulasi pembentukan peraturan daerah tentang anggaran, dalam perkembangannya telah mengalami pergeseran menuju yang lebih baik. Pembentukan undang-undang politik tentang peraturan daerah tentang APBD ideal, jika Peraturan Daerah tentang anggaran sesuai dengan sifat pembentukan peraturan daerah, sesuai dengan hierarki peraturan perundangundangan di Indonesia, sesuai dengan prinsip pembentukan dan prinsip-prinsip dari substansi legislasi, dan dibuat melalui tahapan pembentukan Peraturan Daerah.
\end{abstract}

Kata kunci: Politik Hukum; Peraturan Daerah;

\section{A. PENDAHULUAN}

Anggaran Pendapatan dan Belanja Daerah (APBD) merupakan urat nadi pembangunan yang harus dirumuskan dengan baik, dan bertanggungjawab. Jika tidak akan dapat memberikan dampak, yakni terganggunya proses pembangunan untuk kepentingan rakyat. Kebijakan pembentukan Peraturan Daerah tentang APBD yang ditetapkan oleh Pemerintah Daerah dan DPRD setiap tahun harus dapat mengakomodasi kepentingan publik yang digagas pada setiap tahun melalui forum musyawarah 
pembangunan daerah (Musrenbangda). ${ }^{1}$ Harus didasarkan pada kemauan rakyat, dan orientasi sebesar-besarnya untuk kepentingan rakyat, karena kebijakan anggaran merupakan pintu masuk penetapan program perencanaan pembangunan yang didukung dan disertai dengan pembiayaan/penganggaran.

Politik hukum Pembentukan Peraturan Daerah tentang APBD memberikan arah bagi terwujudnya APBD yang berpihak kepada kesejahteraan rakyat. DPRD sebagai lembaga legislatif daerah, dan representasi kedaulatan rakyat harus benar-benar mampu memposisikan diri sebagai wakil rakyat, ketika menyetujui kebijakan anggaran setiap tahun yang ditetapkan bersama. Hak budgeting yang dimiliki hendaknya berguna untuk kepentingan rakyat bukan kepentingan sesaat, apalagi kepentingan kelompok politik dan atau kelompok usaha. Penetapan kebijakan anggaran setiap tahun melalui penetapan APBD bermaksud agar anggaran Negara/daerah tersebut, sedapat mungkin dilakukan secara efektif dan efisien terutama pada posting belanja aparatur, karena adalah uang rakyat yang harus dialokasikan untuk kepentingan rakyat agar rakyat di daerah memiliki keberdayaan untuk mencapai kehidupan yang sejahtera, sehingga dapat mewujudkan tujuan pembangunan nasional yang diamanatkan oleh konstitusi, yaitu keadilan sosial dan kesejahteraan umum.Banyak daerah mendistribusikan alokasi anggaran untuk kepentingan aparatur tidak berimbang dengan alokasi anggaran untuk kepentingan publik, teristimewa belanja modal untuk pembangunan infrastruktur, pendidikan, dan kesehatan.Penetapan politik anggaran daerah oleh pemerintah daerah dengan DPRD, telah mengalami distorsi, serta merupakan potret buruk bahwa politik anggaran masih jauh dari tujuan dan cita-cita pembangunan nasional, oleh karenanya kebijakan anggaran seperti itu dapat merugikan kepentingan bangsa.

APBD setiap tahun diperuntukkan untuk dua hal pokok, yakni : (1) membiayai kepentingan aparatur berdasarkan kebutuhan dengan mengedepangkan asas efisiensi dan efektivitas; dan (2) membiayai kepentingan pembangunan secara menyeluruh berdasarkan prioritas pembangunan daerah yang ditetapkan oleh pemerintah daerah bersama DPRD, sesuai Rencana Pembangunan Jangka Menengah Daerah (RPJMD), dan (Rencana Kerja Pemerintah Daerah (RKPD), yang tercermin pada Kebijakan Umum Anggaran (KUA), harus menunjukkan keberpihakan pada kepentingan rakyat, karena uang daerah adalah uang rakyat harus bermanfaat untuk kepentingan rakyat. Ketidak berpihakan APBD untuk kepentingan rakyat tersebut sudah saatnya harus diakhiri, jika tidak akan menimbulkan kemiskinan sosial dan ekonomi yang membawa malapetaka bagi kehidupan sosial masyarakat, di antaranya terbatasnya ketersediaan infrastruktur pembangunan jalan, jembatan, dan terbatasnya ketersediaan infrastruktur bidang pendidikan, kesehatan, pertanian dan usaha kecil dan menengah (UKM).

Fakta yang ada menunjukkan bahwa pemerintah daerah dan DPRD saat ini belum memiliki kepedulian untuk membangun daerah dengan baik.APBD merupakan alat stabilitas pembangunan sekaligus sebagai salah satu instrumen pembangunan ekonomi, maka penetapan APBD harus dapat membawa kesejahteraan bagi rakyat, bukan kesensaraan dan kesejahteraan bagi aparatur penyelenggara Negara.

\footnotetext{
${ }^{1}$ Hendra Karianga, Partisipasi Masyarakat dalam pengelolaan keuangan, Bandung Alumni. 2011,Hlm. 


\section{B. ANALISIS DAN PEMBAHASAN}

\section{Politik Hukum Pembentukan Peraturan Daerahtentang APBD}

APBD adalah suatu rencana keuangan tahunan pemerintah daerah yang disetujui oleh DPRD. ${ }^{2}$ Semua Penerimaan Daerah dan Pengeluaran Daerah harus dicatat dan dikelola dalam APBD. Penerimaan dan pengeluaran daerah tersebut, adalah dalam rangka pelaksanaan tugas-tugas desentralisasi. Sedangkan penerimaan dan pengeluaran yang berkaitan dengan pelaksanaan Dekonsentrasi atau Tugas Pembantuan tidak dicatat dalam APBD. APBD merupakan dasar pengelolaan keuangan daerah dalam satu tahun anggaran. APBD merupakan rencana pelaksanaan semua Pendapatan Daerah dan semua Belanja Daerah dalam rangka pelaksanaan Desentralisasi dalam tahun anggaran tertentu. Pemungutan semua penerimaan Daerah bertujuan untuk memenuhi target yang ditetapkan dalam APBD. Demikian pula semua pengeluaran daerah dan ikatan yang membebani daerah dalam rangka pelaksanaan desentralisasi dilakukan sesuai jumlah dan sasaran yang ditetapkan dalam APBD. Karena APBD merupakan dasar pengelolaan keuangan daerah, maka APBD menjadi dasar pula bagi kegiatan pengendalian, pemeriksaan dan pengawasan keuangan daerah.

Politik hukum pembentukan peraturan daerah tentang APBD adalah kebijakan pemerintah dalam memilih cara bagaimana Peraturan Daerahtentang APBD dibuat, ditentukan arah dan isinya serta sifatnya, agar sesuai dengan corak dan tujuan kemasyarakatan serta kebutuhan hukum masyarakat. Dengan demikian hakikat politik hukum pembentukan peraturan daerah tentang APBD adalah kebijakan pemerintahmeliputi : (a) Isi kebijakan yang menjadi dasar pembenaran perbuatan pemerintah dalam menetapkan perda tentang APBD yang berlaku dan (b) cara pemerintah menentukan kebijakan dalam menetapkan Peraturan Daerahtentang APBD yang berlaku. Jika dilihat dari struktur hukum (Kewenangan dan cara pembuatannya) merupakan pesanpesan politik, karena badan atau lembaga Negara yang berwenang membuatnya adalah lembaga politik, tetapi dari segi subtansi hukumnya, adalah hukum yang berlaku merupakan perwujudan kehendak rakyat yang lahir dari proses politik, dari segi budaya hukum merupakan produk budaya, yaitu untuk mewujudkan Peraturan Daerahtentang APBD yang memiliki kepastian hukum, tidak bertentangan dengan kepentingan umum dan peraturan perundang-undangan yang lebih tinggi.

\section{Penentuan Isi Peraturan Daerahtentang APBD Sebagai Ketentuan Hukum Yang Berlaku Dalam Arti Materil}

Suatu ketentuan dapat berlaku efektif jika isinya sesuai dengan prinsip yang berlaku atau diterima umum dalam kehidupan masyarakat yang bersangkutan.Prinsip yang menjadi ukuran isi ketentuan hukum itu adalah sumber hukum materil. Bagi hukum Indonesia, sumber hukum materil itu adalah prinsip menentukan nasib sendiri dan kemandirian daerah, prinsip Negara hukum (kepastian hukum), prinsip yang terangkum dalam Pancasila. ${ }^{3}$

\section{a. Prinsip menentukan Nasib Sendiri dan Kemandirian Daerah}

\footnotetext{
${ }^{2}$ Pasal 1 Butir 8 Undang-Undang Nomor 17 Tahun 2003 tentang Keuangan Negara.

${ }^{3}$ Abdul Latif, Politik Hukum Perundang-Undangan Indonesi, 2010, Hlm. 38
}

Vol. 20 No. 2 November 2018 
Prinsip menentukan nasib sendiri, sejalan dengan Teori Kedaulatan Rakyat, yang intinya berkaitan dengan kekuasaan penyelenggaraan Negara, yang berkenaan dengan dua hal yang menjadi fokus perhatian, yaitu (a) siapa yang memegang kekuasaan tertinggi dalam penyelenggaraan Negara; dan (b) apa saja yang dikuasai oleh pemegang kekuasaan tertinggi itu. Karena itu, sesungguhnya yang berdaulat dalam Negara adalah rakyat. Kehendak rakyat merupakan satu-satunya sumber kekuasaan bagi setiap pemerintah. Dalam konteks historis, Negara Indonesia sebagai Negara yang merdeka sejak Proklamasi Kemerdekaan Tanggal 17 Agustus 1945, berarti bahwa mulai pada saat itu bangsa Indonesia telah mengambil keputusan dan melaksanakan hukumnya sendiri yaitu hukum bangsa Indonesia dengan tata hukumnya yang baru yakni tata hukum Indonesia, termasuk peraturan daerah sebagai bagian dari tata hukum Indonesia.

Prinsip kemerdekaan mempunyai arti, Pertama; menjadikan suatu bangsa menjadi suatu Negara, kedua, pada saat itu pulah Negara yang bersangkutan menentukan atau menetapkan tata hukumnya sendiri. Dengan demikian hanya Negara yang merdeka yang dapat menentukan nasibnya sendiri termasuk menentukan dan menetapkan tata hukumnya sendiri.

Mengenai kemandirian daerah, dalam sistem pemerintahan daerah adalah sistem hubungan dan tata kerja antara pemeritah dengan pemerintahan lokal disatu pihak dan hubungan tata kerja antara Kepala Daerah dengan DPRD.Sementara itu, peraturan daerah merupakan instrumen pengendali terhadap pelaksanaan otonomi daerah.

Esensi otonomi daerah adalah kemandirian atau keleluasaan dan bukan suatu bentuk kebebasan sebagai satuan pemerintahan yang merdeka. Kemandirian mengandung arti daerah berhak mengatur dan mengurus urusan rumah tangga pemerintahannya sendiri, kewenangan mengatur disini, mengandung bahwa daerah bersangkutan berhak membuat produk hukum berupa peraturan daerah, juga tidak bisa terlepas dari konsep susunan Negara Indonesia adalah Negara kesatuan yang berbentuk Republik.

Otonomi adalah kebebasan dan kemandirian satuan pemerintahan lebih rendah untuk mengatur dan mengurus sebagian urusan pemerintahan. Urusan pemerintahan yang boleh diatur dan diurus secara bebas dan mandiri itu menjadi atau merupakan urusan rumah tangga satuan pemerintahan yang lebih rendah tersebut. Kebebasan dan kemandirian merupakan hakekat isi otonomi. ${ }^{4}$

Kebebasan dan kemandirian dalam otonomi bukan kemerdekaan, kebebasan dan kemandirian itu adalah kebebasan dan kemandirian dalam ikatan kesatuan yang lebih besar. Otonomi sekedar sub sistem dari sistem kesatuan yang lebih besar. ${ }^{5}$ Otonomi adalah pembagian kekuasaan bersifat vartikal dalam arti perwujudan kekuasaan itu dibagikan secara vartikal kebawah kepada lembaga-lembaga Negara di bawah lembaga pemegang kedaulatan rakyat, otonomi adalah sub sistem dari Negara kesatuan. Otonomi adalah fenomena Negara kesatuan.

\footnotetext{
${ }^{4}$ Bagir Manan. Perjalanan Historis Pasal 18 UUD 1945 (Perumusan dan Undang-Undang Pelaksanaannya), Unsika, Jakarta, 1992, Halaman 1-2

${ }^{5}$ Bagir Manan. Sistem dan Teknik Pembuatan Peraturan Perundang-Undangan Tingkat Daerah, LPPM Universitas Islam Bandung, 1995, Halaman 4-5
}

Vol. 20 No. 2 November 2018 
Penyelenggaraan otonomi daerah harus selalu berorientasi pada peningkatan kesejahteraan masyarakat dengan selalu memperhatikan kepentingan dan aspirasi yang tumbuh dalam masyarakat. Juga harus menjamin keserasian hubungan antara daerah dengan daerah lainnya, artinya mampu membangun kerja sama antar daerah untuk meningkatkan kesejahteraan bersama dan mencegah ketimpangan antar daerah. Otonomi daerah harus mampu menjamin hubungan yang serasi antar daerah dengan pemerintah, artinya harus mampu memelihara dan menjaga keutuhan wilayah Negara dan tetap tegaknya Negara kesatuan Republik Indonesia dalam rangka mewujudkan tujuan Negara.

Dalam pengertian kemandirian daerah memungkinkan pemerintah daerah berhak menetapkan peraturan daerah untuk melaksanakan otonomi daerah dan tugas pembantuan. Semua urusan, kecuali yang telah ditentukan undang-undang sebagai urusan pemerintah akan menjadi urusan dan kewenangan pemerintah daerah. Semua urusan pemerintahan daerah harus diberi landasan hukum dan landasan kewenangan dalam bentuk peraturan perundang-undangan.Dalam pembentukan peraturan daerah termasuk Peraturan Daerah tentang APBD harus sesuai dengan tujuan Negara, yakni memajukan kesejahteraan umum dan cita hukum Indonesia, yakni Pancasila serta pembentukan peraturan daerah tidak boleh bertentangan dengan peraturan yang lebih tinggi dan tidak boleh bertentangan dengan kepentingan umum.

Adanya kebebasan dan kemandirian daerah, maka daerah dapat membuat peraturan daerah yang sesuai dengan keinginan dan kebutuhan masyarakat di daerah dalam rangka peningkatan pelayanan kepada masyarakat, yang pada akhirnya dapat meningkatkan kesejahteraan masyarakat dalam kerangka Negara kesatuan republik Indonesia.

Peraturan Daerah tentang APBD yang berlaku dalam arti materil adalah Peraturan Daerah tentang APBD yang sesuai dengan keinginan dan kebutuhan masyarakat yang dibentuk atau dibuat dengan tujuan pemberdayaan pemerintah daerah, peningkatan kesejahteraan masyarakat, dibentuk dan dibuat sesuai dengan cita-cita tata hukum Indonesia.

\section{b. Prinsip-Prinsip yang terangkum dalam Pancasila}

Untuk mencapaicita-cita atau tujuan tata hukum Indonesia, maka pembentukan Peraturan Daerah tentang APBD harus selaras dan sesuai dengan cita hukum Indonesia, yaitu Pancasila. Hal ini sesuai dengan alinea ke-IV Pembukaan UUD 1945, “...disusunlah kemerdekaan kebangsaan Indonesia itu dalam suatu Undang- Undang Dasar Negara Indonesia, yang terbentuk dalam suatu susunan Negara Republik Indonesia yang berkedaulatan rakyat dengan berdasarkan kepada Ketuhanan yang Maha Esa, Kemanusiaan yang adil dan beradab, Persatuan Indonesia, dan Kerakyatan yang dipimpin oleh hikmat kebijaksanaan dalam permusyarawatan/perwakilan, serta dengan mewujudkan suatu keadilan sosial bagi seluruh rakyat Indonesia".

Pembentukan peraturan perundang-undangan termasuk Peraturan Daerah tentang APBD harus sesuai dengan cita hukum Indonesia yang terangkum dalam Pancasila.Sejalan dengan asas pembentukan peraturan perundang-undangan yang merupakan suatu pedoman atau suatu rambu-rambu yang harus diikuti oleh pembentuk

Vol. 20 No. 2 November 2018 
undang-undang. Cita hukum adalah suatu apriori yang bersifat normatif sekaligus konstitutif yang merupakan prasyarat transendental yang mendasari tiap hukum positif yang bermartabat. Tanpa cita hukum tidak akanada hukum yang memiliki watak normatif. ${ }^{6}$

Cita hukum Indonesia adalah jantung dan jiwa Negara hukum Indonesia akan menjadi modal reading, ${ }^{7}$ dan sekaligus bintang pemandu dalam pembentukan peraturan perundang-undangan. Sila-sila dalam Pancasila berlaku sebagai cita yang berlaku sebagai bintang pemandu. Sila-sila Pancasila juga berlaku sebagai norma fundamental Negara. Selain itu, Cita Hukum Indonesia merupakan gagasan, rasa, karsa, cipta, dan fikiran, yang ingin diwujudkan. Dalam pembentukan Pembentukan Peraturan Daerah tentang APBD, Isi Peraturan Daerah tentang APBD harus sesuai dengan gagasan, rasa, karsa, cipta, dan fikiran dari masyarakat yang tercermin dalam sila-sila Pancasila dan perkembangan kebutuhan dan aspirasi yang tumbuh dalam masyarakat. Mengapa demikian, karena sila-sila Pancasila merupakan keseluruhan absraksi dari tata nilai yang dianut oleh bangsa Indonesia yang mengarahkan bagaimana rakyat Indonesia seharusnya bertingkah laku baik dalam hubungannya dengan sesama warga masyarakat maupun dalam hubungan dengan kehidupan berbangsa dan bernegara.

Dasar Ketuhanan yang maha Esa menjadi dasar yang memimpin cita-cita Negara kita, yang memberi jiwa kepada usaha menyelenggarakan segala yang benar, adil dan baik, menjadi fundamen moral.Dengan meletakkan dasar moral diatas, Negara dan pemerintahannya memperolah dasar yang kokoh yang memerintahkan berbuat benar, melaksanakan keadilan dan kejujuran serta persaudaraan.

Cita hukum Indonesia melahirkan asas-asas hukum umum dalam pembentukan peraturan perundang-undangan.Asas hukum adalah dasar normatif pembentukan hukum, tanpa asas hukum, hukum positif tidak memiliki makna apa-apa dan kehilangan watak normatifnya, sedangkan pada gilirannya asas hukum membutuhkan bentuk yuridis untuk menjadi aturan hukum positif.Asas hukum adalah konsep- konsep pembimbing bagi pembentukan hukum, yang dalam preses pembentukan hukum dijabarkan lebih lanjut dan dikonkritkan. Asas hukumlah yang memberi roh keberlakuan, atau kekuatan hukum materil kepada norma hukum dan dalam kaitannya dengan kekuatan hukum formal. Asas hukum adalah dasar normatif untuk membedakan antara daya ikat normatif dan keniscayaan yang memaksa.

Asas-Asas hukum umum dalam pembentukan peraturan perundang-undangan nasional yang ditarik dari sila-sila Pancasila, sebagai berikut :

Pertama, Asas ketuhanan yang Maha Esa. Asas ini mengamanatkan bahwa dalam pembentukan peraturan perundang-undangan tidak boleh bertentangan dengan agama atau bersifat menolak atau bermusuhan dengan agama, pembentukan peraturan perundang undangan merupakan pengejewantahan prinsip ketuhanan dalam pelaksanaan perintah Tuhan untuk berbuat baik kepada sesama manusia, dan lingkungannya dalam usaha meraih kebahagiaan.

\footnotetext{
${ }^{6}$ Abdulkadir Besar, Implementasi Cita Hukum dan Penerapan Asas-Asas Hukum Nasional, (Artikel) dimuat dalam Majalah Hukum Nasional, BPHN, No 1 Tahun 1995, halaman. 18-40

${ }^{7}$ Satjipto Rahardjo. Negara Hukum yang Membahagiakan Rakyatnya, Genta Pulishing, Yogyakarta, 2009, Halaman 81-85.
}

Vol. 20 No. 2 November 2018 
Kedua, Asas adil dan beradab, asas ini menghendaki agar pembentukan hukum atau pembentukan peraturan perundang-undangan harus dengan proses dan prosedur yang beradab (amanah, konsisten, dan jujur) dan isinya tidak bertentangan dengan norma-norma sosial lainnya (norma kesusilaan, norma sopan santun, dan norma Agama) serta isinya mengandung keadilan.

Ketiga, Asas Persatuan dan Kesatuan, asas ini mengamanahkan bahwa hukum atau peraturan perundang-undangan Indonesia harus merupakan hukum yang berlaku bagi seluruh bangsa Indonesia. Asas kesatuan dan persatuan tidak mengabaikan suatu kenyataan adanya keaneka ragaman budaya. Secara geografik Negara Indonesia terdiri dari beribu-ribu pulau yang didiami berbagai macam suku yang memiliki keyakinan agama, budaya yang berbeda. Pelaksanaan asas ini, tetap memberi tempat Kekhasan masing-masing daerah untuk tumbuh dan berkembang sesuai dengan ciri khas dan kearifan lokal masing-masing daerah dalam konsep wawasan nusantara.Membangun hukum yang berdasarkan wawasan nusantara berarti membangun hukum dengan memadukan tujuan pembangunan hukum nasional atau menyatukan dengan memperhatikan keaneka ragaman budaya dari penduduk yang mendiami suatu Negara kepulauan dengan tetap memperhatikan kepastian hukum.

Keempat, asas demokrasi mengamanahkan bahwa dalam hubungan antara hukum dan kekuasaan, kekuasaan harus tunduk pada hukum.bukan sebaliknya. Pada akhirnya kekuasaan ada pada rakyat dan wakil-wakilnya. Pengambilan keputusan dalam proses pembentukan peraturan perundang-undangan berdasarkan musyawarah/mufakat. Mekanisme pembentukan peraturan perundang-undangan harus sesuai dengan ketentuan hukum yang berlaku yang telah ditetapkan sebelumnya. Proses politik dalam pembentukan peraturan perundang-undangan, termasuk Peraturan Daerah tentang APBD harus sesuai dengan ketentuan hukum yang berlaku. Kelima, Asas keadilan sosial, mengamanahkan bahwa semua warga Negara mempunyai hak yang sama dan bahwa semua orang sama kedudukannya dihadapan hukum dan pemerintahan.

Asas hukum umum tersebut di atas, akan mengarahkan pembentukan Peraturan Daerahtentang APBD dan berfungsi, Pertama, membimbing para legislator dalam proses pembentukan Peraturan Daerah tentang APBD. Bimbingan itu berlangsung dengan cara menjadikan asas hukum umum, tersebut sebagai pangkal tolak bagi Peraturan Daerahtentang APBD yangakan dibuat atau bagi pembentuk Peraturan Daerahtentang APBD, sekaligus memberikan stimulan bagi tergeraknya nalar dalam menemukan diktum yang bersangkutan. Kedua, meletakkan kekuatan hukum materil pada norma-norma yang terkandung di dalam diktum hukum yang telah ditentukan oleh para legislator.

Cita hukum mempunyai hubungan yang erat dengan asas hukum. Cita hukum; (a) memberi makna pada hukum, (b) membatasi lingkup hukum positif yang dapat dibentuk (c) menetapkan ukuran untuk menilai adil atau tidak suatu hukum positif yang akan dibuat atau telah dibuat, Sedangkan fungsi asas hukum; (a) membimbing

Vol. 20 No. 2 November 2018 
para legislator dalam proses membentuk hukum, (b) memberikan kekuatan hukum materil pada diktum hukum positif yang telah ditemukan oleh legislator.

Subtansi cita hukum Indonesia adalah sebagai idea.Idea keadilan adalah nilai intrinsik. Kalau dirujuk fungsi cita hukum pada butir (a), makna yang diberikan oleh cita hukum kepada hukum positif yang akan dibuat, atau peraturan perundangundangan yang akan dibuat adalah hukum positif tersebut menjadi berkemampuan menyatakan janji intrinsik, yakni untuk keadilan, ia menjadi bermakna bagi masyarakat.

Pada fungsi cita hukum butir (b), batas itu adalah keadilan, artinya, bila diktum hukum yang dibuat tidak dapat dipertanngung jawabkan pada keadilan, maka ia kehilangan maknanya sebagai hukum, karena watak normatifnya tinggal dengan sendirinya. Jadi, fungsi membatasi, adalah untuk menjaga agar hukum hasil proses pembentukan para legislator, tetap dalam proporsi keadilan, terjaga sifat pro keadilannya.

Janji intrinsik tersebut, terimplementasi melalui fungsi asas hukum tersebut pada butir (a), dalam wujud : pembimbingan terhadap para legislator dalam proses pembentukan hukum. Merujuk pada salah satu deskripsi pengertian asas hukum bahwa "asas hukum adalah dasar normatif pembentukan hukum; tanpa asas hukum, hukum positif tidak memiliki makna apa-apa, dan kehilangan watak normatifnya", maka pembimbingan itu niscaya bertujuan agar muatan dari hukum positif yang sedang dalam proses pembentukan, berkualifikasi pro keadilan.

Merujuk pada fungsi asas hukum butir (b), pemberian kekuatan hukum materil baru terjadi setelah diktum hukum positif yang bersangkutan lulus dari saringan : Fungsi Cita hukum butir (a) dan (b), dan fungsi asas hukum butir (a), yang ketigatiganya berkriteria pro keadilan. Akhirnya hukum positif keluaran dari proses yang begitu terorganisasi, dengan sendirinya menyandang sifat pro keadilan. Sedangkan pada fungsi cita hukum butir (c), dapat diketahui bahwa fungsi ini bekerja yaitu ia menilai hukum positif yang telah diberlakukan. Apakah hukum positif ternyata tidak memenuhi keadilan, dialah yang membuka peluang untuk diadakan pengujian materi oleh lembaga peradilan.

Cita hukum melahirkan asas hukum, selanjutnya asas hukum diekstrak untuk melahirkan hukum positif.Fungsi cita hukum yang bersifat pro keadilan mendapatkan fungsi asas hukum padanannya yang juga bersifat pro keadilan dan pada ujungnya menghasilkan hukum positif yang bersifat pro keadilan juga. ${ }^{8}$

Mengenai persolan bagaimana peraturan daerah tentang APBD dibuat dan ditentukan isinya serta sifat fungsinya, tentu harus sesuai dengan cita hukum Indonesia dan asas-asas hukum umum pembentukan peraturan perundang-undangan yang tersirat dalam cita hukum Indonesia itu sendiri. Cita hukum Indonesia memberi makna bahwa Peraturan Daerahtentang APBD sebagai ketentuan hukum yang berlaku, membatasi lingkup peraturan daerah yang dapat dibentuk, sebagai ukuran untuk menilai adil atau tidak adilnya peraturan yang mengatur pembentukan

${ }^{8}$ Abdul Kadir Besar, 1995, Op. Cit, Halaman. 31.

Vol. 20 No. 2 November 2018 
peraturan daerah, Sedangkan asas hukum akan berfungsi membimbing para anggota DPRD dan kepala daerah beserta jajarannya dalam proses pembentukan peraturan daerah tentang APBD, memberikan kekuatan hukum materiil pada diktum Peraturan daerah tentang APBD yang telah ditemukan oleh anggota DPRD dan Kepala daerah beserta jajarannya.

\section{PENUTUP}

Politik Hukum Pembentukan Peraturan Daerah tentang APBD pada hakikatnya memuat kebijakan-kebijakan daerah yang direncanakan akan dilaksanakan dalam rangka mewujudkan kesejahteraan masyarakat.Regulasi pembentukan peraturan daerah tentang APBD, dalam perkembangannya telah mengalami pergeseran kearah yang lebih baik.

Politik hukum pembentukan Peraturan daerah tentang APBD yang ideal, jika Peraturan Daerah tentang APBD sesuai dengan hakikat pembentukan Peraturan Daerah, sesuai dengan hierarki peraturan perundang-undangan di Indonesia, sesuai dengan asas pembentukan dan asas materi muatan peraturan perundang-undangan, dan dibuat melalui tahapan pembentukan Peraturan Daerah.

\section{DAFTAR PUSTAKA}

Abdul Latif, Hukum dan Kebijakan (Beleidsregel) pada Pemerintahan Daerah, UII Press, Yogyakarta. 2005.

Abdul Latif Politik Hukum Perundang-Undangan Indonesi, Naska buku.2010.

Abdulkadir Besar. Implementasi Cita Hukum dan Penerapan Asas-Asas Hukum Nasional, (Artikel) dimuat dalam Majalah Hukum Nasional, BPHN, No 1 Tahun 1995.

Bagir Manan. Masalah Tata Negara Indonesia, Edisi II, Cetakan I Alumni Bandung, Bandung. 1997.

Bagir Manan Sistem dan Teknik Pembuatan Peraturan Perundang-Undangan Tingkat Daerah, LPPM Universitas Islam Bandung. 1995.

Gofar, Fajrimei, "Perda Bermasalah atau Perda di Permasalahkan. Kompas 26 Agustus 2003.

Hendra Karianga, Partisipasi Masyarakat dalam pengelolaan keuangan, Bandung Alumni. 2011.

Hendra Karianga, Politik Hukum dalam Pengelolaan Keuangan Daerah, Jakarta, Kencana Prenadamedia Group. 2013

Laica Marzuki, M, Prinsip-Prinsip Pembentukan Peraturan Daerah, Makalah dimuat dalam Jurnal Konstitusi, Volume 6 Nomor 4, Nopember 2009.

Vol. 20 No. 2 November 2018 
Mahfud MD, Muh. Dasar \& Struktur Ketatanegaraan Indonesia, Rineka Cipta, Jakarta. 2001.

Mahfud MD Membangun Politik Hukum, Menegakkan Konstitusi, Jakarta, Rajawali Pers. 2012.

Nuhrawati, A. (018. Hukum Dan Demokrasi Jalan Menuju Kesejahteraan Rakyat. Pleno Jure, 7(2), 16-27.

Hidjaz, Kamal. "Role of Local Institutions in Improving Human Resources at Government System in Indonesia." JL Pol'y \& Globalization 14 2013: 37.

Sajtipto Rahardjo, Ilmu Hukum, Alumni, Bandung. 1986.

Sajtipto Rahardjo, Negara Hukum yang Membahagiakan Rakyatnya, Genta Pulishing, Yogyakarta. 2009. 